Krzysztof Koźbiał

\title{
Referenda w systemie politycznym Republiki Czeskiej
}

\begin{abstract}
Abstrakt
Republika Czeska jest jednym z tych krajów europejskich, w których bezpośrednie instrumenty demokratyczne, takie jak referenda, są rzadko stosowane na szczeblu państwowym. W Republice Czeskiej w ten sposób zdecydowano jedynie o przystąpieniu kraju do Unii Europejskiej (2003). Z drugiej strony, na poziomie lokalnym czeskie doświadczenia z referendami są bogate. W latach 2006-2021 przeprowadzono ponad 300 referendów, średnio ponad 20 rocznie. Problematyka poruszana w tych referendach obejmowała kwestie infrastruktury, lokalizacji elektrowni wiatrowych czy składowania odpadów radioaktywnych. W przyszłości szersze niż dotychczas wykorzystanie referendów w czeskim systemie politycznym zależeć będzie m.in. od wyniku wyborów parlamentarnych, które odbędą się jesienią 2021 r. Czeska Partia Piratów, która ma duże szanse na zwycięstwo w tych wyborach, opowiada się za korzystaniem $\mathrm{z}$ tego typu głosowania znacznie częściej niż dotychczas.
\end{abstract}

Słowa kluczowe: Republika Czeska, demokracja bezpośrednia, referendum, czeski system polityczny, Czeska Partia Piratów

\section{Wprowadzenie}

Republika Czeska jest państwem, w którym instytucje demokracji bezpośredniej stosuje się (na szczeblu ogólnopaństwowym) niezwykle rzadko. W zasadzie rozstrzyganie istotnych spraw poprzez odwołanie się do woli społeczeństwa jest obce dla czeskiego systemu politycznego. Gdyby jednak przyjrzeć się temu problemowi na poziomie lokalnym, to perspektywa się zmienia, bowiem referenda znajdują zastosowanie w praktyce. Istnieje zatem wyraźna dychotomia, w zależności od poziomu analizy zjawiska. 
W czeskim systemie partyjnym funkcjonują ugrupowania, które opowiadają się za istotnym zwiększeniem roli demokracji bezpośredniej w procesie podejmowania decyzji w państwie. Można zatem mówić o perspektywach rozwoju tego sposobu rozstrzygnięć, tym bardziej, że jedno z tych ugrupowań po wyborach planowanych na początek października 2021 r. może stać się główną siłą w czeskiej polityce.

Najistotniejsze są, według mnie, odpowiedzi na następujące pytania badawcze dotyczące tej problematyki: 1) dlaczego do tej pory referenda na poziomie ogólnopaństwowym są w Republice Czeskiej rzadkością? 2) z jakiego powodu na szczeblu lokalnym referenda cieszą się zainteresowaniem jeśli chodzi o rozstrzyganie określonych problemów? 3) jaka jest przyszłość instrumentów demokracji bezpośredniej w Republice, wziąwszy szczególnie pod uwagę fakt, iż coraz bardziej zauważalną rolę w polityce wewnętrznej Czech odgrywają partie wspierające taki sposób demokratycznych rozstrzygnięć?

W celu odpowiedzi na tak sformułowane pytania badawcze zastosowano typowe dla nauk o polityce i administracji metody badawcze, tj.: analizę systemową, analizę treści zawartości dokumentów oraz analizę historyczną.

Odnosząc się do tytułowego problemu należy podkreślić, iż referenda są jedną z odmian demokracji bezpośredniej, najpowszechniej stosowaną i najbardziej znaną. Niektórzy wręcz - i nie bez racji - utożsamiają demokrację bezpośrednią $\mathrm{z}$ referendami ${ }^{1}$. Według definicji demokracja bezpośrednia przewiduje bezpośredni udział wyborców w wypełnianiu funkcji publicznych, podejmowanie decyzji w określonych sprawach ${ }^{2}$. Należy uznać, iż w prawidłowo funkcjonującym - w pewnym sensie komplementarnym - systemie politycznym rozwiązania takie powinny uzupełniać dominującą formę demokracji pośredniej. Najczęściej w rozstrzyganiu tych dylematów, które są w danych społeczeństwach uznawane za najbardziej istotne, zarówno na szczeblu państwa, regionu, jak i lokalnej wspólnoty.

\section{Doświadczenia z przeszłości}

Czeskie doświadczenia związane z referendami są z historycznego punktu widzenia niezwykle ubogie. Po powstaniu niepodległej Czechosłowacji w $1918 \mathrm{r}$. decydując o podstawach ustrojowych nowego państwa pierwotnie dążono do wzorowania się na rozwiązaniach szwajcarskich. Jednak konstytucja z $1920 \mathrm{r}$. wspominała tylko o referendum fakultatywnym, do którego mógł się odwołać wyłącznie rząd. Mógł to zrobić w przypadku gdyby parlament odrzucił rządowy

M. Marczewska-Rytko, Demokracja bezpośrednia w teorii i praktyce politycznej, Lublin 2001, s. 110-111; M. Musiał-Karg, Referenda w państwach europejskich. Teoria, praktyka, perspektywy, Toruń 2008, s. 61.

2 M. Marczewska-Rytko, op.cit., s. 31-32. 
projekt ustawy. Referendum nie mogło obejmować projektów ustaw, które zmieniałyby konstytucję. Nigdy jednak nie skorzystano z tej formy głosowania ${ }^{3}$.

Powojenne konstytucje socjalistycznej Czechosłowacji nie przewidywały stosowania instrumentów demokracji bezpośredniej. Był to zasadniczo instrument niemile widziany przez władze państw socjalistycznych, twory niedemokratyczne. W okresie istnienia powojennego wspólnego państwa Czechów i Słowaków nie odbyło się żadne referendum. Dopiero przed rozpadem Czechosłowacji przyjęto ustawę konstytucyjną (18 VII 1991 r.), która mogła stanowić podstawę dla referendum w całym państwie. Przedmiotem ewentualnego głosowania mogły być kwestie dotyczące systemu konstytucyjnego państwa, względnie wystąpienie z ówczesnej federacji ${ }^{4}$.

Mimo istnienia formalnych możliwości przeprowadzenia referendum „rozwodowego" Czechów i Słowaków także wtedy nie skorzystano z tego instrumentu. Podział na Republikę Czeską i Republikę Słowacką (państwa niezależne od 1 I 1993 r.) nastąpił bez odwołania się do woli obywateli. Można jedynie domniemywać, iż powodem swoistego strachu polityków przed przeprowadzeniem referendum był fakt, że w obu wspomnianych grupach narodowościowych nie było przekonania co do konieczności podziału wspólnego państwa. Pod koniec 1992 r. badania opinii publicznej wskazywały, że jedynie 21\% Czechów i 18\% Słowaków chciało podziału państwa ${ }^{5}$.

Potwierdzają to badania przeprowadzone w październiku 2017 r. (nieomal 25 lat po rozpadzie Czechosłowacji). Wskazywały one, że $22 \%$ pytanych w Czechach i $23 \%$ na Słowacji uważało, iż podział państwa bez referendum był posunięciem słusznym bądź raczej słusznym, przeciwnego zdania było - odpowiednio - aż 68 i $67 \%$ pytanych ${ }^{6}$. Był to swego rodzaju ewenement, bowiem w przypadku rozpadu innych państw (ZSRR, Jugosławia) referenda „niepodległościowe” były przeprowadzane.

\section{Referenda w przepisach prawnych Republiki Czeskiej}

Referendum nie ma trwałych podstaw prawnych w analizowanym państwie. Obecne ustawodawstwo Republiki Czeskiej w bardzo powściągliwy sposób odnosi się do instrumentów demokracji bezpośredniej. W konstytucji uchwalonej

3 K. Koźbial, Direct democracy in the political system of the Czech Republic: current status and prospects for the future, „Political Preferences” 2018, vol. 21, s. 18; A. Rytel-Warzocha, Referendum ogólnokrajowe w państwach Europy Środkowo-Wschodniej, Warszawa 2011, s. 92-93.

Ibidem, s. 101-102.

J. Tomaszewski, Czechosłowacja, Warszawa 1997, s. 261.

6 Rozdělení Československa: 25 let od Izniku samostatné ČR a SR, s. 4, https://cvvm.soc.cas.cz/ media/com_form2content/documents/c2/a4464/f9/po171205.pdf. 
16 XII 1992 r. w żadnym miejscu nie znajdziemy takich określeń jak „demokracja bezpośrednia” czy „referendum”. W artykule 2, ust. 2, ustawodawca przewidział, iż ustawa konstytucyjna może określić, kiedy lud wykonuje władzę państwowa bezpośrednio ${ }^{7}$. W konsekwencji każda próba przeprowadzenia referendum wymaga przyjęcia specjalnej ustawy przez parlament. Przepisów mówiących o demokracji bezpośredniej nie znajdziemy także w Karcie Podstawowych Praw i Wolności, stanowiącej część czeskiego porządku konstytucyjnego. Jedynie art. 21 Karty nie wprost dopuszcza bezpośrednie głosowanie stanowiąc, iż obywatele maja prawo do udziału w zarzadzaniu sprawami publicznymi bezpośrednio albo poprzez wolne wybory swoich przedstawicieli ${ }^{8}$.

Odnosząc się do referendum w czeskim systemie prawnym M. Krzywoszyński zalicza Czechy do grupy demokracji pół-przedstawicielskich, czyli takich gdzie konstytucje dopuszczają stosowanie referendów jedynie fakultatywnych ${ }^{9}$. Jednakże z powodu ograniczonej liczby zastosowań w praktyce ustrojowej stwierdzenie to budzi wątpliwości i wydaje się przesadne, bowiem Czechy są przede wszystkim demokracją przedstawicielską.

O referendum wspomina ustawa o samorządzie terytorialnym z 1990 r. Dwa lata później weszła w życie również ustawa o lokalnych wyborach i referendach, w której przewidziano możliwość referendum inicjowanego oddolnie. Z tej możliwości nie korzystano jednak do końca ubiegłego wieku ${ }^{10}$, a także w pierwszych dwóch dziesięcioleciach obecnego wieku. Aktualnie obowiązuje ustawa przyjęta pod koniec 2003 r., znowelizowana w 2008 r. (tzw. prawo o referendum lokalnym $)^{11}$.

$\mathrm{Na}$ jej podstawie istnieje możliwość decydowania w referendum o konkretnych sprawach związanych z lokalnymi społecznościami. W tego rodzaju głosowaniach mogą brać udział osoby dysponujące prawem głosu. Aby takie głosowanie doszło do skutku wniosek muszą poprzeć minimalne liczby obywateli. W gminach liczących do 3 tys. mieszkańców jest to przynajmniej 30\% uprawnionych do głosowania, do 20 tys. $20 \%$, do 200 tys. $10 \%$ a ponad 200 tys. $6 \%$ mających prawo głosu. Z zasady są to głosowania jednodniowe, są ważne, jeżeli weźmie w nich udział przynajmniej 35\% uprawnionych do oddania głosu. Rezultat

$7 \quad$ Konstytucja Republiki Czeskiej z 16 grudnia 1992 r., tłumaczenie i wstęp M. Kruk, Warszawa 2000, s. 35 .

$8 \quad$ Ibidem, s. 75.

9 M. Krzywoszyński, Referendum ogólnokrajowe w Europie: teorie, praktyki, analogie, Poznań 2017, s. 65.

10 M.L. Smith, The uneasy balance between participation and representation: local direct democracy in the Czech Republic, [w:] Local Direct Democracy in Europe, red. T. Schiller, Wiesbaden 2011, s. 35.

11 Zákon o místním referendu a o zmèně některých zákonů, ze dne 11. prosince 2003, „Sbírka Zákonů České Republiky” 2004, nr 22, https://www.zakonyprolidi.cz/cs/2004-22\#cast1 (18 V 2021). 
jest wiążący jeśli za określoną decyzją opowie się większość oraz gdy będzie ona stanowiła co najmniej $25 \%$ osób uprawnionych do oddania głosu ${ }^{12}$. Zorganizowanie ponownego głosowania $\mathrm{w}$ tej samej sprawie jest dopuszczalne dopiero po upływie 2 lat. Pytanie referendalne musi być sformułowane w taki sposób, aby można było na nie odpowiedzieć „tak” lub „nie” ${ }^{13}$. Nie wszystkie kwestie mogą być poddane pod referendum. Przykładowo nie jest to dopuszczalne w przypadku odwołania lub powołania organów gminy lub też wyboru czy odwołania starosty, względnie primatora miasta.

Z kolei od 2011 r. na poziomie czeskich krajów (regionów, odpowiedników polskich województw) także dopuszczalne jest referendum ${ }^{14}$. Podczas niego obywatele uprawnieni do głosowania mogą rozstrzygać o sprawach należących do kompetencji krajów - jako jednostek samorządu terytorialnego. Głosowanie może się odbyć w wypadku akceptacji przez zgromadzenie regionalne (Zastupitelstvo) lub wtedy, gdy odpowiedni wniosek złoży komitet przygotowujący referendum poparty podpisami przynajmniej $6 \%$ obywateli uprawnionych do oddania głosu na obszarze regionu. Referendum regionalne jest ważne jeżeli uczestniczy w nim co najmniej 35\% obywateli figurujących w spisie uprawnionych do oddania głosu a rezultat jest wiążący, gdy za określonym rozwiązaniem opowie się większość stanowiąca równocześnie $25 \%$ uprawnionych do głosowania. Ustawa wymienia także sprawy, wobec których nie można zastosować regionalnego referendum, np. wybór i odwołanie przewodniczącego komitetu regionalnego (hejtmana) czy uchwalenie budżetu regionu ${ }^{15}$.

Na poziomie regionalnym i lokalnym istnieją zatem znacznie dalej idące prawne uwarunkowania przeprowadzania głosowań w sprawach adekwatnych do kompetencji organów samorządu terytorialnego niż ma to miejsce na poziomie ogólnopaństwowym. Znajdują one zastosowanie w praktyce.

\section{Praktyka ustrojowa na szczeblu ogólnopaństwowym}

Od momentu niezależności Republiki Czeskiej (czyli przez nieomal 30 lat) nie wprowadzono w życie rozwiązań dających możliwość odwołania się do głosu obywateli. Mimo propozycji i podejmowanych prób, jak np. pomysłu socjal-

12 Wyjątkiem są kwestie podziału lub połączenia miejscowości, ich części lub gmin kiedy to wymagana jest zgoda ponad połowy uprawnionych do głosowania.

13 Občanské aktivity, http://www.mvcr.cz/clanek/obcanske-aktivity-118893.aspx (19 V 2021).

14 Zákon o krajském referendu a o změně některých zákonů, ze dne 9. března 2010, „Sbírka Zákonů České Republiky” 2010, nr 118, http://www.psp.cz/sqw/sbirka.sqw?r=2010\&cz=118 (20 V 2021). Wyjątkiem są referenda na obszarze Pragi, będącej równocześnie gminą i regionem, które przeprowadzane są w oparciu o ustawę dotyczącą referendów lokalnych.

15 Ibidem. 
demokratów aby przeprowadzić w 1999 r. głosowanie na temat członkostwa w NATO, uczestnicy czeskiego systemu politycznego nie zdecydowali się na stosowanie tegoż instrumentu ${ }^{16}$. Wyraźnie wskazuje to na stosunkowo tradycjonalistyczne podejście czeskich decydentów politycznych do tego problemu.

W latach 1993-2003 miało miejsce aż 19 prób wprowadzenia do ustawodawstwa prawa dotyczącego ogólnokrajowych referendów. Najwięcej tego typu propozycji - aż 11 - złożyła Czeska Partia Socjaldemokratyczna (ČSSD) i Komunistyczna Partia Czech i Moraw (KSČM) - 4. Żadna z nich nie zakończyła się skutecznie gdyż Izba Poselska takich regulacji nie przyjęla ${ }^{17}$.

Jedyne dotychczas referendum ogólnopaństwowe odbyło się w dniach 13 i 14 VI 2003 r. i dotyczyło członkostwa Republiki w Unii Europejskiej. Wzięło w nim udział 55,21\% uprawnionych do głosowania, z czego 77,33\% opowiedziało się za akcesją do UE. Referendum było ważne, a jego wynik wiążący ${ }^{18}$. Jednokrotne zastosowanie tego instrumentu demokracji bezpośredniej w ciągu prawie 30 lat niezależności skłania do wniosku, iż bezsprzecznie nie było to rozwiązanie, do którego władze tego państwa przywiązywałyby jakiekolwiek znaczenie. Bez wątpienia było to także pochodną braku historycznych doświadczeń.

Przeprowadzenie głosowania na temat akcesji do UE było możliwe na podstawie odpowiedniej ustawy konstytucyjnej, którą Izba Poselska przyjęła w październiku 2002 r. (Senat miesiąc później) ${ }^{19}$. Było to dopuszczalne na podstawie wspomnianego art. 2 ust. 2 konstytucji. Parlament czeski już w 1999 r. podjął próbę przyjęcia ustawy, która umożliwiłaby głosowanie na temat akcesji do Unii lecz wówczas nie zyskało to akceptacji. Referendum z 2003 r. było ważne bez względu na frekwencję. Podczas prac nad ustawą przygotowującą głosowanie uznano, iż istnieje zbyt duże ryzyko niskiej frekwencji ${ }^{20}$. Dlatego zrezygnowano z określenia minimum koniecznego dla ważności głosowania.

Po 2003 r. na terytorium Republiki nie przeprowadzano więcej referendów ogólnopaństwowych. Swego rodzaju ciekawostkę związaną z tą formą podejmowania decyzji mogą stanowić jedynie „wirtualne referenda”21. Przykładowo,

16 M.L. Smith, op.cit., s. 34.

17 P. Jüptner, P. Valušová, I. Kruntorádová, Participation and Elements of Direct Democracy in the Czech Republic: Part I, „Viešoji Politika ir Administravimas” 2014, vol. 13, nr 4, s. 650.

18 Referendum o pristoupení České republiky k Evropské unii konané ve dnech 13.-14.06.2003, https://www.volby.cz/pls/ref2003/re13?xjazyk=CZ (20 V 2021).

19 Ústavní zákon o referendu o přistoupení České republiky k Evropské unii a o změnè ústavního zákona č. 1/1993 Sb., Ústava České republiky, ve znění pozdějšich ústavních zákonů, Ústavní zákon ze dne 14. listopadu 2002, „Sbírka Zákonů České Republiky” 2002, nr 515, https://www. zakonyprolidi.cz/cs/2002-515 (20 V 2021).

20 Obawy te wiązano $\mathrm{z}$ tradycyjnie niską frekwencją $\mathrm{w}$ wyborach do drugiej izby parlamentu - Senatu i z wyborami lokalnymi, bowiem w wyborach do Izby Poselskiej frekwencja była znacznie wyższa.

$21 \quad$ K. Koźbiał, op.cit., s. 22. 
równocześnie z brytyjskim głosowaniem na temat opuszczenia UE przez Wielką Brytanię tygodnik „Reflex” przeprowadził głosowanie dotyczące hipotetycznego wyjścia Czech z Unii. 80\% spośród ponad 40 tys. głosujących opowiedziało się w Internecie za opuszczeniem organizacji ${ }^{22}$.

Podobną akcją, nawiązującą do demokracji bezpośredniej, było zbieranie podpisów pod projektem odnowienia istnienia Czechosłowacji, w 100 rocznicę jej powstania. Podpisy takie, ze skromnym jak dotąd powodzeniem, zbiera Ruch na rzecz Odnowienia Czechosłowacji (Hnutí za obnovení Československa). Z oddanych na ich stronie internetowej prawie 15 tys. głosów (stan na $31 \mathrm{~V} 2021$ r.) prawie $84,5 \%$ popiera tego rodzaju inicjatywęę). Prawo czeskie nie przewiduje jednak możliwości doprowadzenia do realnego głosowania poprzez zebranie określonej liczby głosów pod projektem.

\section{Praktyka ustrojowa na szczeblu lokalnym}

Na szczeblu lokalnym referendum jest stosowane w praktyce wręcz bardzo często. Dochodziło do tego stopniowo, według M.L. Smitha zmiana pod tym względem zarysowała się po 2000 r., co należałoby wiązać z działaniami organizacji pozarządowych, które mobilizowały na poziomie lokalnym mieszkańców, aby przeciwstawić się pewnego rodzaju zamiarom, równocześnie prowadziły kampanie przedreferendaln $e^{24}$. Za przełomowe uznaje się referendum w Taborze w 2000 r., kiedy to przy frekwencji 37\% odrzucono projekt budowy dróg przez park botaniczny. Obywatele miasta uznali, iż referendum będzie jedyną możliwością aby zakończyć kilkuletni spór dotyczący wspomnianej inwestycji i faktycznie tak się stało.

Nie było to pierwsze tego rodzaju głosowanie. Początkowo $(1992,1993)$ przeprowadzano je przede wszystkim aby dokonać zmian terytorialnych, połączyć pewne gminy lub - najczęściej - wydzielić nowe. Po 2000 r. ten typ głosowań ograniczył się do pojedynczych przypadków. Nabrały z kolei znaczenia decyzje odnoszące się do spraw związanych ze środowiskiem ${ }^{25}$.

Tematyka ta z czasem zaczęła dominować w lokalnych głosowaniach. Najczęściej wiązała się ona z lokalizacją miejsc odpadów promieniotwórczych, powstawaniem elektrowni wiatrowych czy też inwestycjami infrastrukturalnymi.

22 Referendum nanečisto: Pro odchod Česka $z$ EU Se vyjádřilo 80 procent hlasujících [23.06.2016], http://www.reflex.cz/clanek/anketa/72285/referendum-nanecisto-pro-odchod-ceska-z-eu-se-vyjadrilo-80-procent-hlasujicich.html (22 V 2021).

23 Úvodní stránka, https://ceskoslovensko2018.wordpress.com/ (31 V 2021).

24 M.L. Smith, op.cit., s. 37.

25 P. Jüptner, P. Valušová, I. Kruntorádová, op.cit., s. 655. 
Jak oblicza M.L. Smith, w latach 2000-2008 na 151 przeprowadzonych głosowań $91(60 \%)$ dotyczyło spraw powiązanych ze środowiskiem ${ }^{26}$.

Według danych czeskiego Ministerstwa Spraw Wewnętrznych w latach 2006-2021 w Republice Czeskiej odbyło się 314 referendów lokalnych, ostatnie z nich $14 \mathrm{~V} 2021 \mathrm{r}^{27}$. Opierając się na tym spisie można wskazać kilka problemów bez wątpienia wiodących. Należały do nich głosowania dotyczące:

a) budowy elektrowni wiatrowych lub fotowoltaicznych (np. gmina Líchkov w 2007 r., Bousin 2008, Sudice 2010);

b) rozbudowy infrastruktury drogowej i kanalizacji (Suché Lazce 2012, Písek 2013, Borová 2014);

c) składowania odpadów radioaktywnych pochodzących z dwóch czeskich elektrowni atomowych (Hubenov, Dvorce 2007);

d) zgody na budowę elementów radarowych amerykańskiej tarczy antyrakietowej (Zaječov, Vševíly, Vesela, Láz, Štítov - wszystkie 2007) ${ }^{28}$.

Widoczne jest zatem, iż mimo głosowań lokalnych wpływały one na problematykę międzynarodową - najlepszym przykładem są głosowania w sprawie dotyczącej elementów amerykańskiej tarczy antyrakietowej. Co interesujące, tematy te wzbudziły szerokie zainteresowanie - głosowało nawet ponad $70 \%$ uprawnionych. Wynik głosowania nie był wiążący a z czasem Amerykanie i tak odstąpili od tego pomysłu, w związku z czym konsekwencje tych referendów nie nabrały znaczenia. Podobne emocje wywoływały propozycje składowania odpadów radioaktywnych w proponowanych lokalizacjach, które w poszczególnych gminach podczas głosowania zgromadziły nawet ponad $80 \%$ uprawnionych do głosu. Referenda te wypadły negatywnie dla proponowanych rozwiązań.

Emocje wywołała także sprawa dworca kolejowego w Brnie gdzie lokalne władze zakładały przebudowę przebiegu linii kolejowej i wybudowanie nowego dworca dalej od centrum, czemu sprzeciwiali się mieszkańcy. W 2004 r. przeprowadzono na ten temat głosowanie, w którym $86 \%$ poparło projekt modernizacji lecz z zachowaniem dworca w dotychczasowym miejscu. Z uwagi na niską frekwencję referendum nie było ważne. W kolejnym głosowaniu w 2016 r., także nieważnym $\mathrm{z}$ uwagi na udział $\mathrm{w}$ nim jedynie $23,8 \%$ uprawnionych do oddania głosu, jego uczestnicy ponownie opowiedzieli się za takim rozwiązaniem jak 12 lat wcześniejej.

Statystycznie największe zainteresowanie wzbudziły referenda dotyczące powstania nowych gmin (średnia frekwencja ponad 76\%), składowania odpadów

26 M.L. Smith, op.cit., s. 40.

27 Místní referenda v České Republice 2006-2020, www.mvcr.cz (24 V 2021).

28 Ibidem.

29 Referendum o nádraží v Brně není platné. Většina lidí Se vyjádřila Proti jeho odsunu z centra [8 X 2016], https://zpravy.aktualne.cz/referendum-o-nadrazi-v-brne-neni-kvuli-nizke-ucasti-platne/r 6d3d37688d9511e683920025900fea04/ (24 V 2021). 
radioaktywnych (prawie 73\%) i elementów radaru mającego wchodzić w skład tarczy antyrakietowej (prawie 66\%). Najmniejszą frekwencję odnotowano przy sprawach dotyczących kwestii finansowych $(28,5 \%)$ i edukacji (prawie $31 \%)^{30}$.

Dotychczas nie odbyło się natomiast żadne referendum regionalne. Próby doprowadzenia do niego podejmowano w Kraju Usteckim, miało ono dotyczyć limitu wydobycia węgla brunatnego. Pomysł ten popierali m.in. były premier Jiří Paroubek i prezydent Miloš Zeman. Do realizacji nie doszło gdyż uznano, iż tego rodzaju głosowanie przekraczałoby kompetencje regionu ${ }^{31}$.

Przytoczone przykłady dowodzą, iż na poziomie lokalnym, najczęściej w niewielkich gminach, referenda są skutecznym narzędziem wyrażania opinii przez lokalną społeczność, także w sprawach, które należy uznać za niezwykle ważne nie tylko dla tychże społeczności. Uzasadnione wydaje się stwierdzenie, iż z lokalnych głosowań wypływają doświadczenia jednoznacznie świadczące o tym, iż tego rodzaju rozstrzyganie problemów wywołuje zainteresowanie uprawnionych do głosu. Mimo to podkreśla się, nie bez racji, że referenda lokalne nie mają żadnego zakotwiczenia w czeskiej konstytucji, co stanowi ich słabośćc ${ }^{32}$.

\section{Przyszłość referendum w Republice Czeskiej}

Przyszłość referendum, jako najbardziej znanej instytucji demokracji bezpośredniej, będzie zależna od kilku czynników, które można zidentyfikować. Po pierwsze, wbrew przypuszczeniom, członkostwo państwa w Unii Europejskiej nie wymusiło - jak na razie - poddawania pod ocenę wyborców spraw dotyczących integracji europejskiej3. Po drugie, istotnym czynnikiem mogącym wpłynąć na wprowadzenie w życie instrumentów bezpośredniego decydowania o istotnych sprawach państwa jest nastawienie obywateli. Nie dysponujemy szerokimi źródłami na ten temat. Jednak badania opinii publicznej z lutego 2020 r. wyraźnie wskazują, iż wśród obywateli Republiki nie dominuje chęć podejmowania decyzji w istotnych sprawach dotyczących funkcjonowania państwa. $75 \%$ pytanych wyraziło zdanie, iż to obywatele powinni artykułować w sposób bezpośredni opinię

30 P. Jüptner, P. Valušová, I. Kruntorádová, Participation and Elements of Direct Democracy in the Czech Republic: Part II, „Viešoji Politika ir Administravimas” 2015, vol. 14, nr 2, s. 281.

31 Starosta Litvínova: Krajské referendum o prolomení Tebach limitů není namístě [11 VII 2014], http://www.parlamentnilisty.cz/arena/monitor/Starosta-Litvinova-Krajske-referendum-o-pro lomeni-tezebnich-limitu-neni-namiste-326458 (22 IV 2021); Paroubek: M. Zeman pro krajské referendum v Oczce limitů těžby hnědého uhli [21 X 2014], http://www.parlamentnilisty.cz/ politika/politici-volicum/Paroubek-M-Zeman-pro-krajske-referendum-v-otazce-limitu-tezb y-hnedeho-uhli-342526 (22 IV 2021).

32 O. Hamulák, Referendum v českém právním prostředí. „Právo. Časopis pro právni teorii a praxi” 2008, č. 2, s. 31-32.

33 M. Musiał-Karg, op.cit., s. 194. 
na temat problemów lokalnych (łączne wskazania „tak” i „raczej tak”), tylko $46 \%$ pytanych wyraziło taką opinię dotyczącą spraw ogólnopaństwowych ${ }^{34}$. Nie wskazuje to zatem na szerokie przekonanie o sprawczości instytucji demokracji bezpośredniej, co z pewną wstrzemięźliwością każe spoglądać na możliwość ich zastosowania w Czechach. Jednocześnie potwierdza to sensowność stosowania tego rodzaju rozwiązań na szczeblu właśnie lokalnym.

Po trzecie, być może za najistotniejsze należy uznać chęć wykorzystania tego rodzaju instrumentu przez poszczególne ugrupowania polityczne. Pod tym względem istnieją - według Autora - przesłanki aby tak się stało.

Po wyborach do Izby Poselskiej czeskiego parlamentu w 2017 r. znalazły się w nim dwie partie wspierające ten sposób rozstrzygania istotnych kwestii ${ }^{35}$. Były to Wolność i Demokracja Bezpośrednia (SPD - Svoboda a př́má demokracie) i Czeska Partia Piratów (Česká Pirátská Strana). W obu przypadkach w kadencji 2017-2021 partie te wprowadziły po 22 przedstawicieli do 200-osobowej Izby i pozostawały w opozycji. W obu przypadkach mamy też do czynienia z licznymi odwołaniami do konieczności stosowania także i w Czechach demokracji bezpośredniej.

Partia SPD, kierowana przez ekscentrycznego polityka Tomio Okamurę, demokrację bezpośrednią wpisała nawet do swej nazwy. Jednoznacznie zatem opowiada się za stosowaniem tego rodzaju rozwiązań w praktyce ustrojowej państwa czeskiego, odniesienia do tego zagadnienia znaleźć można w pierwszych zdaniach programu ruchu ${ }^{36}$. Demokracja bezpośrednia ma umożliwić obywatelom szerszy niż dotąd udział w zarządzaniu państwem. Równocześnie w programie wyraźnie podkreślono, że ma to być równocześnie remedium na wręcz uratowanie demokracji w Czechach. SPD opowiada się przede wszystkim za stosowaniem referendum $\mathrm{w}$ istotnych dla państwa problemach, bezpośrednim wyborem hejtmanów (stojących na czele samorządowych krajów w Republice) oraz starostów miast. Równocześnie politycy wybierani w ten sposób mogliby być także odwoływani. Co interesujące, miałoby to dotyczyć także głowy państwa ${ }^{37}$. Mimo tak zdecydowanego stanowiska w tej sprawie ruch opiera swój przekaz do wyborców także na innych hasłach wyborczych (np. przed wyborami w 2017 r. odnosiły się one w dużej mierze do postaw antyimigranckich), w związku z czym trudno jednoznacznie rozstrzygnąć jakie elementy decydują o wyborczym poparciu dla $\mathrm{SPD}^{38}$.

34 Zájem o politiku a názory na podílení se občanů na rozhodování - únor 2020, https://cvvm.soc. cas.cz/media/com_form2content/documents/c2/a5157/f9/pd200306.pdf.

35 W wyborach zwyciężyło ugrupowanie ANO 2011 obecnego premiera Andreja Babiša uzyskując prawie 30\% głosów, przed ODS (11,3\%), Piratami (10,8\%), SPD (10,6\%), KSČM (7,8\%) i ČSSD (7,3\%).

36 Politický Program SPD, https://www.spd.cz/program-vypis/ (26 V 2021).

37 Ibidem.

38 Trudno uznać, iż jest to zwracanie uwagi na kwestie demokracji bezpośredniej. 
Dla samego Okamury nie jest to zresztą pierwsze ugrupowanie, w którym próbuje wspierać postulat stosowania w praktyce referendum ${ }^{39}$.

Partia Piratów, obecnie trzecia siła w Izbie Poselskiej, również popiera rozwiązania z zakresu demokracji bezpośredniej. Elementy te akcentuje szczególnie w tzw. programie długofalowym ugrupowania ${ }^{40}$ zwracając uwagę na możliwość tak bezpośrednich wyborów polityków zajmujących określone miejsca, jak i perspektywę ich odwołania (władza ustawodawcza, wykonawcza, sądownictwo, urzędy państwowe). Przegląd propozycji tego ugrupowania pozwala na stwierdzenia, że w sposób szerszy niż SPD odnosi się ono do możliwych zastosowań instrumentów bezpośredniego decydowania przez obywateli.

Piraci postulują wprowadzenie do czeskiego systemu politycznego referendów o charakterze wiążącym, które odnosiłyby się albo do propozycji inicjatyw ustawodawczych, albo do kwestii istotnych z punktu widzenia państwa (np. zmiany w konstytucji, członkostwo w organizacjach międzynarodowych, traktaty międzynarodowe $)^{41}$. Piraci dopuszczają także wprowadzenie w życie wspomnianej inicjatywy ustawodawczej związanej z określonym projektem, który ostatecznie mógłby podlegać głosowaniu w czasie referendum (jeśli parlament nie odniósłby się do projektu w danym czasie). Według propozycji ugrupowania obywatelom przysługiwałoby także tzw. weto ludowe, polegające na zebraniu wystarczającej liczby podpisów uprawnionych do głosowania pod petycją uchylenia ustawy przyjętej przez parlament (i w tym przypadku ostateczna decyzja byłaby podjęta poprzez referendum $)^{42}$.

$\mathrm{Z}$ drugiej strony instrumenty demokracji bezpośredniej nie cieszą się powodzeniem wśród pozostałych aktorów czeskiej sceny partyjnej: ANO 2011, ČSSD czy ODS. Jedynie Komunistyczna Partia Czech i Moraw (KSČM) pozytywnie, choć jednocześnie bardzo ogólnie, odnosi się do instrumentów demokracji bezpośredniej zwracając uwagę na konieczność stworzenia prawnych podstaw dotyczących referendum konstytucyjnego, weta ludowego, inicjatywy ludowej czy też kwestii związanych z referendami regionalnymi i lokalnymi ${ }^{43}$. Są to zatem dość ogólne sformułowania.

Z wymienionych ugrupowań pozytywnie oceniających możliwości wprowadzenia w życie instrumentów demokracji bezpośredniej najistotniejsze wydaje

$39 \quad$ K. Koźbiał, op.cit., s. 25.

40 https://www.pirati.cz/program/dlouhodoby/prima-demokracie/ (26 V 2021).

41 Równocześnie zwraca się uwagę, iż obywatel powinien być przed referendum dokładnie poinformowany zarówno o argumentach „za” jak i „przeciw” danej propozycji, co zasadniczo przypomina rozwiązania szwajcarskie.

42 https://www.pirati.cz/program/dlouhodoby/prima-demokracie/ (26 V 2021).

43 Volebni program KSČM pro volby do Poslanecké sněmovny Parlamentu České republiky 2017, https://www.kscm.cz/sites/default/files/soubory/Program\%20KS\%C4\%8CM/volebni_program_kscm_pro_volby_do_ps_pcr_2017.pdf (26 V 2021). 
się stanowisko Partii Piratów. Na skutek pandemii koronawirusa, przy stosunkowo chaotycznych działaniach rządu Andreja Babiša, ugrupowanie to ma istotne szanse na odniesienie zwycięstwa podczas wyborów do parlamentu czeskiego, które planowane są na 8-9 X 2021 r. Według sondażowych badań Median koalicja wyborcza Piratów i ugrupowania STAN (także obecnego w obecnej Izbie Poselskiej) mogłaby liczyć w kwietniu 2021 r. na poparcie 27,5\% wyborców, rządzące ANO na $21 \%$ (przy zauważalnej tendencji spadkowej) ${ }^{44}$. Z kolei SPD mogłoby liczyć na 11,5\% głosów.

Gdyby faktycznie przełożyło się to na wyniki wyborcze wówczas perspektywy wprowadzenia instrumentów demokracji bezpośredniej w Republice Czeskiej nie wyglądałyby najgorzej. $\mathrm{W}$ tym momencie ${ }^{45}$ trudno jednak o tym przesądzać. Wydaje się jednak, że Piraci będą mieli okazję aby ten postulat swojego programu wprowadzić w życie. Wiele wskazuje na to, że będą głównym ugrupowaniem tworzącym przyszły rząd Republiki Czeskiej.

\section{Zakończenie}

Dotąd referenda w Republice Czeskiej stosunkowo często stosowano na poziomie wspólnot lokalnych, gdzie rozstrzygano o wielu sprawach, wykraczających także poza sprawy miejscowe. Z kolei na szczeblu ogólnopaństwowym odbyło się tylko jedno głosowanie - w sprawie członkostwa Czech w Unii Europejskiej. Obywatele analizowanego państwa mają zatem doświadczenia związane z korzystaniem z instrumentów demokracji bezpośredniej, lecz polityczni decydenci - jak się wydaje - nie chcą tych doświadczeń przenieść na szczebel państwowy.

Trudno jednoznacznie odpowiedzieć na pytanie czy referenda na szczeblu ogólnopaństwowym mają szanse stać się częściej stosowanym niż dotąd instrumentem w systemie politycznym Republiki Czeskiej. Czynnikiem sprzyjającym jest wysokie poparcie dla Partii Piratów, która ma duże szanse na zwycięstwo w jesiennych wyborach do parlamentu. Pozwala to z pewnym optymizmem spojrzeć na przyszłość referendum w czeskim systemie politycznym, choć decyzja tego dotycząca z pewnością nie będzie łatwa.

44 Snémovní volební model duben 2021, https://www.median.eu/cs/wp-content/uploads/2021/05/ Volby_2021_04_opr.pdf (27 V 2021).

45 Artykuł oddaje stan wiedzy autora na dzień $31 \mathrm{~V} 2021 \mathrm{r}$. 


\section{Abstract}

Krzysztof Koźbiał

\section{Referenda in the political system of the Czech Republic}

The Czech Republic is one of those European countries where direct democratic instruments, such as referendums, are rarely resorted to at the state level. Only the country's accession to the European Union (2003) was decided in this way in the Czech Republic.

On the local level, on the other hand, the Czech experience with referendums is rich. Between 2006 and 2021, more than 300 referendums were held, an average of more than 20 per year. The issues dealt with in these referendums included infrastructure issues, the location of wind power plants or the storage of radioactive waste.

The future of the use of referendums more widely than before in the Czech political system will depend, among other things, on the outcome of the parliamentary elections to be held in the autumn of 2021. The Czech Pirate Party, which has a significant chance of winning this election, is in favour of using this type of voting far more often than before.

Keywords: Czech Republic, direct democracy, referendum, Czech political system, the Czech Pirate Party

\section{References}

ČTK, Referendum o nádraží v Brně není platné. Vètšina lidí Se vyjádřila Proti jeho odsunu $z$ centra [8 X 2016], https://zpravy.aktualne.cz/referendum-o-nadraz i-v-brne-neni-kvuli-nizke-ucasti-platne/r 6d3d37688d9511e683920025900fea $04 /$.

CVVM, Rozdělení Československa: 25 let od Izniku samostatné ČR a SR, https:// cvvm.soc.cas.cz/media/com_form2content/documents/c2/a4464/f9/po171205.pdf.

CVVM, Zájem o politiku a názory na podílení se občanů na rozhodování - únor 2020, https://cvvm.soc.cas.cz/media/com_form2content/documents/c2/a5157/f9/pd200306.pdf.

Hamulák, O., Referendum v českém právním prostředí. „Právo. Časopis pro právni teorii a praxi” 2008, č. 2. 
Jüptner, P., Valušová, P., Kruntorádová, I., Participation and Elements of Direct Democracy in the Czech Republic: Part I, „Viešoji Politika ir Administravimas” 2014, vol. 13, nr 4.

Jüptner, P., Valušová, P., Kruntorádová, I., Participation and Elements of Direct Democracy in the Czech Republic: Part II, „Viešoji Politika ir Administravimas” 2015, vol. 14, nr 2.

Konstytucja Republiki Czeskiej z 16 grudnia 1992 r., tłumaczenie i wstęp M. Kruk, Warszawa 2000.

Koźbiał, K., Direct democracy in the political system of the Czech Republic: current status and prospects for the future, „Political Preferences” 2018, vol. 21.

Krzywoszyński, M., Referendum ogólnokrajowe w Europie: teorie, praktyki, analogie, Poznań 2017.

KSČM, Volební program KSČM pro volby do Poslanecké sněmovny Parlamentu České republiky 2017, https://www.kscm.cz/sites/default/files/soubory/Program\%20KS\%C4\%8CM/volebni_program_kscm_pro_volby_do_ps_pcr_ 2017.pdf.

Marczewska-Rytko, M., Demokracja bezpośrednia w teorii i praktyce politycznej, Lublin 2001.

Median, Snémovní volební model duben 2021, https://www.median.eu/cs/wp-content/uploads/2021/05/Volby_2021_04_opr.pdf.

Musiał-Karg, M., Referenda w państwach europejskich. Teoria, praktyka, perspektywy, Toruń 2008.

MVCR, http://www.mvcr.cz/clanek/obcanske-aktivity-118893.aspx.

MVCR, Mistní referenda v České Republice 2006-2020, www.mvcr.cz.

parlamentnilisty.cz, Paroubek: M. Zeman pro krajské referendum v Oczce limitů těžby hnědého uhli [21 X 2014], http://www.parlamentnilisty.cz/politika/ politici-volicum/Paroubek-M-Zeman-pro-krajske-referendum-v-otazce-limi tu-tezby-hnedeho-uhli-342526.

parlamentnilisty.cz, Starosta Litvínova: Krajské referendum o prolomení Tebach limitů není namistě [11 VII 2014], http://www.parlamentnilisty.cz/arena/ monitor/Starosta-Litvinova-Krajske-referendum-o-prolomeni-tezebnich-limitu-neni-namiste-326458.

Pirátská strana, https://www.pirati.cz/program/dlouhodoby/prima-demokracie/. Referendum o pristoupení České republiky $k$ Evropské unii konané ve dnech 13.-14.06.2003, https://www.volby.cz/pls/ref2003/re13?xjazyk=CZ.

Reflex.cz, Referendum nanečisto: Pro odchod Česka $z$ EU Se vyjádřilo 80 procent hlasujicich [23 VI 2016], http://www.reflex.cz/clanek/anketa/72285/referendum-nanecisto-pro-odchod-ceska-z-eu-se-vyjadrilo-80-procent-hlasujicich. html.

Rytel-Warzocha, A., Referendum ogólnokrajowe w państwach Europy Środkowo-Wschodniej, Warszawa 2011. 
Smith, M.L., The uneasy balance between participation and representation: local direct democracy in the Czech Republic, [in:] Local Direct Democracy in Europe, ed. T. Schiller, Wiesbaden 2011.

SPD, Politický Program SPD, https://www.spd.cz/program-vypis/.

Tomaszewski, J., Czechosłowacja, Warszawa 1997.

Ústavní zákon o referendu o pristoupení České republiky k Evropské unii a o zmèně ústavního zákona č. 1/1993 Sb., Ústava České republiky, ve znění pozdèjších ústavních zákoni̊, Ústavní zákon ze dne 14. listopadu 2002, „Sbírka Zákonů České Republiky” 2002, nr 515, https://www.zakonyprolidi.cz/cs/2002-515.

Úvodní stránka, https://ceskoslovensko2018.wordpress.com/.

Zákon o krajském referendu a o změně některých zákonů, ze dne 9. března 2010, „Sbírka Zákonů České Republiky” 2010, nr 118, http://www.psp.cz/sqw/sbirka.sqw? $\mathrm{r}=2010 \& \mathrm{cz}=118$.

Zákon o místním referendu a o změně některých zákonů, ze dne 11. prosince 2003, „Sbírka Zákonů České Republiky” 2004, nr 22, https://www.zakonyprolidi.cz/ cs/2004-22\#cast 1 .

Krzysztof Koźbiał - dr hab. politologii, prof. Uniwersytetu Jagiellońskiego, kierownik Zakładu Studiów nad Europą Środkową w Instytucie Studiów Europejskich Uniwersytetu Jagiellońskiego w Krakowie. ORCID: 0000-0001-6124-5341 